
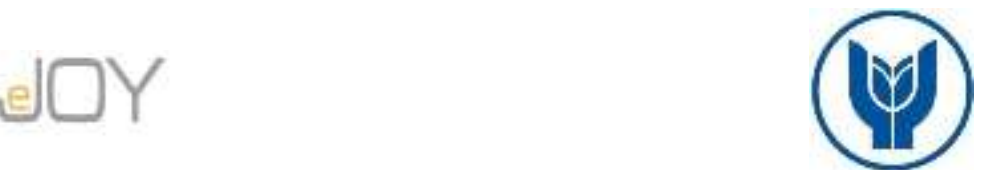

Anbar, D., Çiftçioğlu, B., A., Anbar, A. / Journal of Yasar University, 2020, 15/58, 221-235

\title{
Kurumsal Sosyal Sorumluluk Algısının İşveren Markası Algısı Üzerindeki Etkisini Belirlemeye Yönelik Bir Araştırma ${ }^{1}$
}

\section{A Research on the Effect of Corporate Social Responsibility Perception on Employer Brand Perception}

\author{
Deniz ANBAR, Bursa Uludağ Üniversitesi, Türkiye, denizanbar@gmail.com \\ Orcid No: 0000-0003-0019-0265 \\ Başak Aydem ÇİFTÇíoĞLU, Bursa Uludağ Üniversitesi, Türkiye, aydemaydemir@uludag.edu.tr \\ Orcid No: 0000-0003-2908-7093 \\ Adem ANBAR, Bursa Uludağ Üniversitesi, Türkiye, aadem@uludag.edu.tr \\ Orcid No: 0000-0001-8909-6851
}

\begin{abstract}
Öz: Bu çalıșmanın temel amacı, ișletmelerin kurumsal sosyal sorumluluk faaliyetleri ile ișveren markası algısı arasında bir ilișki olduğu hipotezini test etmektir. Bu kapsamda, Bursa Uludağ Üniversitesi İktisadi ve İdari Bilimler Fakültesi bölümlerinin üçüncü ve dördüncü sinıflarında okuyan ögrenciler çalışmanın ana kütlesini oluşturmuştur. Veriler 869 ögrenciden oluşan bir örneklemden anket yoluyla toplanmış ve verilerin analizinde tanımlayıcı istatistikler ve regresyon analizi kullanılmıştır. Çalışmanın bulguları genel olarak ögrencilerin hem kurumsal sosyal sorumluluk algı düzeylerinin hem de işveren markası algı düzeylerinin yüksek olduğunu göstermiştir. Regresyon analizi sonucunda elde edilen bulgulara göre, ögrencilerin kurumsal sosyal sorumluluk algı düzeylerinin ișveren markası algı düzeyleri üzerinde anlamlı ve pozitif bir etkiye sahip olduğu sonucuna ulaşılmıștır.
\end{abstract}

Anahtar Sözcükler: Kurumsal Sosyal Sorumluluk, Işsveren Markası, İşveren Çekiciliği, Işsveren Markası Algısı JEL Siniflandırmasi: M10, M12, M14

\begin{abstract}
The main purpose of this study is to test the hypothesis that there is a relationship between the corporate social responsibility activities of the enterprises and the perception of employer brand. In this context, the students studying in the third and fourth classes of the Bursa Uludag University Faculty of Economics and Administrative Sciences constituted the universe of the study. Data were collected from a sample of 869 students by using questionnaire and descriptive statistics and regression methods were used for data analysis. The findings of the study showed that both the levels of corporate social responsibility perception and the level of employer brand perception were high in general. According to the results obtained from the regression analysis, it was concluded that the corporate social responsibility perception levels of students had a significant and positive effect on the employer brand perception.
\end{abstract}

Keywords: Corporate Social Responsibility, Employer Brand, Employer Attractiveness, Employer Brand Perception JEL Classification: M10, M12, M14

\section{Giriş}

1980'li yılar itibariyle küresel ekonomi ve iş dünyasında yaşanan köklü değişimler, ekonominin temel birimleri olan işletmeler üzerinde önemli etkiler yaratmıştır. Küreselleşme ile birlikte değişen rekabet anlayışı, bilgi ve teknolojide yaşanan gelişmeler neticesinde, nihai amaçları kar elde etmek olan işletmelerin varlıklarını istikrarlı bir şekilde devam ettirmeleri daha zor hale gelmiştir (Alparslan ve Aygün, 2013: 436). Yaşanan bu değişimlere bağlı olarak, işletmelerin içinde bulundukları topluma, çevreye ve hatta dünyaya olan etkileri arttıkça aynı paralellikte yükümlülükleri de artmıştır. Bu kapsamda, içinde bulundukları çevrenin bir parçası olan işletmeler, bu sistemde meydana gelen değişimlere ayak uydurmak zorunda kalmışlardır. İşletmelerin bu sürece uyum sağlamalarına katkı sağlayan önemli unsurlardan biri olarak "sosyal sorumluluk" kavramı ortaya çıkmıştır (Sağır, 2016: 292).

Sosyal sorumluluk kavramı, ortaya çıktığı dönemden bu yana önemli değişimlere uğramış ve bugün gelinen noktada işletmelerin sosyal yaşamın bir gereği olarak varlıklarını sürdürmelerine vurgu yapan önemli bir olgu haline gelmiştir. Hem akademik literatürde hem de iş çevresinde önemi ve gerekliliği konusunda fikir birliğine varılan sosyal sorumluluk kavramı, işletmelerin kendi amaçlarını gerçekleştirmelerinin yanı sıra topluma karşı olan yükümlülüklerin bilincine varılmasını da zorunlu hale getirmiştir (Jain, 2013: 85). Bu nedenle, işletmeler için ekonomik anlamda verimlilik ve etkinlik sağlamak kadar, toplumsal anlamda fayda yaratmak da önemli hale gelmiştir (Albinger ve Freeman, 2000: 243).

Gittikçe artan rekabet ortamında işletmelerin maddi ve maddi olmayan varlıklarının sürdürülebilirliğini sağlamak, küresel pazar içinde rakiplerinden farklılaşmak ve bu sayede rekabet üstünlüğü elde etmek için büyük ölçüde nitelikli ve yetenekli çalışanlara sahip olmaları gerekmektedir (Tanwar ve Prasad, 2016: 854; Reis ve Braga, 2016: 103). Nitelikli insan sermayesinin öneminin farkına varan işletmeler, uzun dönemli çözüm olarak işveren markası olgusunu değişik

\footnotetext{
${ }^{1}$ Bu çalışma, Deniz Anbar'ın Prof.Dr. B. Aydem Çiftçioğlu danışmanlığında tamamladığı yüksek lisans tezinden türetilmiş ve II. International Conference on Emprical Economics and Social Science (ICEESS' 19)'da sözlü bildiri olarak sunulmuştur.
}

Makale Gecmiși / Article History

Başvuru Tarihi / Date of Application 
açılardan gündeme taşımışlardır (Roy, 2008: 110; Mölk ve Aurer, 2018: 485). İşveren markası, mevcut ve potansiyel çalışanların zihinlerinde işletmenin "tercih edilen bir işyeri”" olarak algılanmasına katkı sağlayan unsurlardan biridir (Srivastava vd., 2017: 661; Tüzüner, 2019: 48). İşveren markas1, algıya dayanan bir kavram olmakla birlikte, mevcut ve potansiyel çalışanların işletmeye ilişkin farkındalıklarını yönetmeyi hedefleyen bir süreçtir (Kuşçu ve Yolbulan Okan, 2010: 121; Rampl ve Kenning, 2014: 219). İşveren markası alg1 düzeyini etkileyen çalışma ortamı, çalışan odaklı değerlere sahip olma, performans yönetimi, liderlik, müşteri ilişkileri, yenilik ve yaratıcılık gibi birbiriyle ilişkili birçok unsur bulunmaktadır. Bu unsurlardan biri de kurumsal sosyal sorumluluk faaliyetleridir (Raj ve Jyothi, 2011: 7-8; Kucherov ve Zavyalova, 2012: 87-89). Dolayısıyla, bu çalışmanın amacı kurumsal sorumluluk algı düzeyinin işveren markası algısı üzerinde bir etkisinin olup olmadığını ampirik olarak ortaya koymaya çalışmaktır. Yabancı literatürde, kurumsal sosyal sorumluluk faaliyetleri ile işveren markası algısı arasındaki ilişkiyi inceleyen çalışmalar olmasına karşın, ulusal literatür oldukça kısıtlıdır. Bu nedenle, çalışmanın özellikle ulusal literatüre önemli katkılar sağlayacağı düşünülmektedir.

Çalışma, beş bölümden oluşmaktadır. İlk olarak, kavramsal çerçeve bölümünde, kısaca işveren markası kavramına ve işveren markası ile kurumsal sosyal sorumluluk ilişkisine değinilmiştir. İkinci bölümde ulusal ve uluslararası literatüre, üçüncü bölümde araştırmanın metodolojisine, dördüncü bölümde bulgulara değinilmiş ve çalışma, sonuç ve tartışma bölümüyle sonlandırılmıştır.

\section{Kavramsal Çerçeve ve Literatür}

\section{1. İşveren Markası}

İşletmeler arasında yaşanan “yetenek savaşları”, sürdürülebilir rekabet avantajı sağlamak isteyen işletmeleri potansiyel çalışanları kendilerine çekmenin ve mevcut çalışanları ellerinde tutmanın yollarını aramaya itmiştir. Bu bağlamda, işveren markası kavramı ilk olarak, "yetenek savaşı" olarak da ifade edilen işgücü piyasasındaki eğilimlerin demografik, ekonomik, sosyo-politik ve teknolojik değişimler tarafından etkilendiği 1990'lı yıllarda ortaya çıkmıştır. (Hillebrandt ve Ivens, 2012: 52; Ergun ve Tatar, 2018: 110; Sharma ve Prasad, 2018: 538). Simon Borrow, 1990 yılında İngiltere'de ortaya çıkan "işveren markası” kavramının yaratıcısı olarak kabul edilmektedir. İşveren markası, pazarlama ilkelerinin insan kaynakları yönetimine (yani iç pazarlamaya) uygulanması ile gündeme gelmiş ve çalışanların işyeri seçimine ilişkin yapılan çalışmalarla gelişme göstermiştir (Kara, 2013: 40; Alnıçık vd., 2014: 337; Güler ve Basım, 2018: 3661).

Ambler ve Barrow (1996), işveren markasını, "istihdamın sağladığı fonksiyonel, ekonomik ve psikolojik faydalar paketi” olarak tanımlamışlar ve istihdam eden şirket ile özdeşleştirmişlerdir. Burada, fonksiyonel ve ekonomik faydalar; fiziksel çalışma ortamının iyileştirilmesi, ücret ve ödeme olanaklarının adil olması, sosyal imkânlar gibi faydaları ifade ederken, psikolojik faydalar; çalışanların öz değerlerini koruma, kendini özgür bir şekilde ifade edebilme, kişisel gelişim ve imaj oluşturma gibi çalışanların ihtiyaçlarına cevap verebilen duygusal yararları ifade etmektedir (Yorulmaz ve Yavan, 2018: 1013; Köse ve Yeygel Çakır, 2018: 168).

Backhaus ve Tikoo (2004), işveren markasını, "potansiyel çalışanların ve ilgili paydaşların belirli bir işletmeye ilişkin farkındalıklarını ve algılarını yönetmek için hedeflenen, uzun vadeli bir strateji” olarak tanımlamışlardır. Diğer bir tanıma göre, işveren markası, işletmenin potansiyel çalışanları çekmek, mevcut çalışanları elde tutmak ve motive etmek amacıyla işletmenin değer sistemini, politikalarını ve davranışlarını kapsayan bir unsurdur (Bellou, 2015: 1203; Fernandez-Lores vd., 2016: 122). İşveren markası, işletmenin insan kaynakları politikaları ile pazarlama faaliyetlerinin etkin bir şekilde uygulanmasını sağlayan bir aracı görevi görmektedir (Narcıkara vd., 2016: 47). Dolayısıyla, bir işletmenin güçlü bir işveren markasına sahip olabilmesi için insan kaynakları fonksiyonlarını etkin bir şekilde yerine getirmesi gerekmektedir.

Özetle, işletmenin bir işveren olarak rakiplerine kıyasla farklı olduğu özellikleri ve nitelikleri ön plana çıkararak mevcut ve potansiyel çalışanlar tarafından çalışılmak istenen bir işveren olarak algılanmasını ifade eden işveren markası, bir taraftan potansiyel çalışanları etkileyerek işletme bünyesine katmayı sağlarken, diğer taraftan mevcut çalışanların işletmeye olan bağl1lıklarını artırmaktadır (Güngördü vd., 2014: 3; Kahveci, 2018: 20; Köse, 2018: 824). İşveren markası, nitelikli potansiyel çalışanları işletmeye çekerek ve mevcut çalışanların bağlılıklarını arttırarak, maliyetleri azaltmakta, müşteri memnuniyetinde artış sağlamakta ve finansal performansın artışına yol açmaktadır (Barrow ve Mosley, 2005: 8287; Dursun ve Eriş, 2018: 162).

\subsection{Kurumsal Sosyal Sorumluluk ve İşveren Markası Arasındaki İlişki}

Kurumsal sosyal sorumluluk faaliyetleri, işletmeler için güçlü marka algısı yaratmak ve rekabet üstünlüğü sağlamak, olumlu marka imajı ve farkındalığı yaratmak gibi faydalar sağlamanın dışında güçlü bir işveren markası yaratılmasında da üzerinde önemle durulması gereken stratejik bir araçtır (Ötken ve Okan, 2015: 126; Maheshwari ve Shankar Yadav, 2015: 602). İşletmelerin kurumsal sosyal sorumluluk faaliyetleri, işletmeyi işgücü piyasasında başarıyla konumlandırma açısından kilit bir rol oynamaktadır. Sosyal sorumluluk faaliyetleri yürüten işletmeler, iyi çalışma koşulları, maddi imkanlar ve paydaşlarına sundukları katkılar nedeniyle piyasada itibar değeri yüksek işveren olarak algılanmaktadır (Tkalac Vercic ve Sincic Coric, 2018: 446). Kurumsal sosyal sorumluluk faaliyetlerinin işletme stratejilerine uygulanması sadece potansiyel çalışanları işletmeye çekmekle kalmamakta, aynı zamanda mevcut çalışanların işletmeye karşı aidiyet duygularını pekiştirmekte, çalışanların motivasyonunu ve verimliliğini artırmaktadır (Bustamante ve Brenninger, 2013: 6; Kashikar-Rao, 2014: 194; Bustamante, 2018: 9). 
Potansiyel çalışan ve organizasyon uyumu yaklaşımına göre, iş arayan adaylar kişilik özelliklerine uygun niteliklere sahip işletmeleri tercih etmektedirler (Klimkiewicz ve Oltra, 2017: 451; Hinson vd., 2018: 1). Bu uyumu yakalamaya çalışan potansiyel çalışanlar işveren tercihi yaparken benzer değerleri ve fikirleri paylaştıkları işletmelerin bir parçası olmak istemektedirler. Bu bağlamda, kurumsal sosyal sorumluluk algısı yüksek olan, diğer bir deyişle, işletmelerin kurumsal sosyal sorumluluk faaliyetleri yürütmeleri gerektiğini düşünen potansiyel çalışanların, kurumsal sosyal sorumluluk faaliyetlerine önem veren işletmeleri tercih edecekleri söylenebilir (Klimkiewicz ve Oltra, 2017: 451).

\subsection{Carroll Piramidi}

Carroll (1979, 1991)'un dört boyutlu sosyal sorumluluk modeli, toplumun işletmelerden beklediği çeşitli sorumlulukları göstermektedir. Her sorumluluk işletmenin toplam sosyal sorumluluğunun bir parçasıdır. Model, kurumsal sosyal sorumluluğu dört sorumluluktan oluşan çok boyutlu bir yapı olarak ele almaktadır. Bunlar; ekonomik, yasal, etik ve gönüllü sorumluluklardır. Şekil 1, "Carroll Piramidi” olarak da ifade edilen kurumsal sosyal sorumluluğun dört boyutunu göstermektedir. Piramidin en alt tabakasını oluşturan ekonomik sorumluluklar, işletmelerin temel ve öncelikli sosyal sorumluluğudur. Diğer bir deyişle, işletmeler toplumun temel ekonomik birimleri olup, toplumun istediği mal ve hizmetleri üretmek ve belirli karla onlara satmak işletmelerin temel sorumluluklarıdır (Carroll, 1979: 500; Carroll, 1991: 41). Toplum, işletmelerin sadece kar amacıyla faaliyet göstermelerini onaylamamakta, aynı zamanda faaliyetlerini yasalara uygun olarak sürdürmelerini istemektedir (Carroll, 1991: 41). Dolayısıyla ekonomik sorumluluklardan sonra ikinci boyut, yasal sorumluluklardır. Bir sonraki işletme sorumluluğu etiktir. Her ne kadar ilk iki unsur etik kuralları somutlaştırmış olsa da, tam olarak kanunlarla düzenlenmemiş ama toplumun işletmelerden beklediği ilave davranış ve faaliyetler vardır. Etik sorumluluklar tam olarak tanımlanamamaktadır ve işletmenin uğraştığı en zor konulardan biridir. Etik sorumluluklar, “toplumun işletmelerden yasal gerekliliklerin üzerindeki beklentileridir” şeklinde ifade edilebilir (Carroll, 1979: 500). Son olarak, işletmenin iyi bir kurumsal vatandaş olması, diğer bir deyişle, işletmenin finansal ve insan kaynaklarıyla topluma katkıda bulunması ve yaşam kalitesini iyileştirmesi beklenmektedir (Carroll, 1991: 42). Gönüllülük esasına dayanan ve işletmelerin sosyal görevler üstlenme isteğine bağlı olan bu sorumluluk boyutu, gönüllü sorumluluklardir.

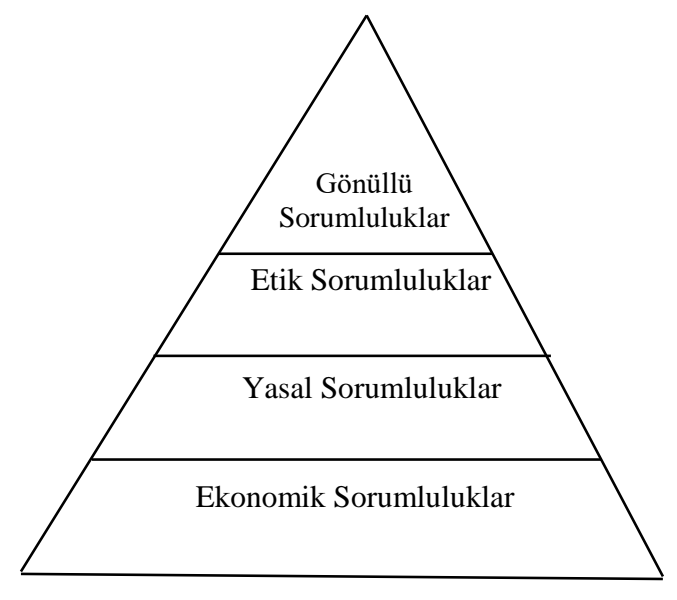

Şekil 1. Kurumsal Sosyal Sorumluluk Piramidi

\subsection{Literatür Taraması}

İşveren markası algısı veya işveren çekiciliği üzerine yapılan çalışmalar iki genel grup altında toplanabilir. Birinci grupta; potansiyel adayların iş başvurusu yaparken işverenlerde (kurumlarda) aradıkları faktörleri veya mevcut çalışanların çalıştıkları kurumu tercih etmelerinde ve kurumda kalmalarında etkili olan faktörleri (iş-yaşam dengesi, çalışma ortamı, kariyer gelişim firsatları, ürün kalitesi gibi) ortaya koymaya yönelik çalışmalar yer almaktadır. İkinci grupta ise, işveren markası/işveren çekiciliği ile ilişkili olduğu/olacağı düşünülen (örgütsel bağlılık, iş tatmini, kurumsal sosyal sorumluluk gibi) faktörler arasındaki ilişkileri inceleyen çalışmalar yer almaktadır. Burada, bu çalışmanın amacıyla da uyumlu olarak, kurumsal sosyal sorumluluk ile işveren markası arasındaki ilişkiyi inceleyen çalışmaların bulgularına yer verilmeye çalışılmıştır.

Albinger ve Freeman (2000), bir kurumun sosyal sorumluluk performansının iş arayanların algılanan işveren çekiciliği üzerindeki etkisini araştırmışlar ve kurumsal sosyal sorumluluk performansı ile iş arayanların algılanan işveren çekiciliği arasında olumlu bir ilişki olduğu bulgusuna ulaşmışlardır. Greening ve Turban (2000), üniversite öğrencilerinden oluşan bir örneklem kullanarak yaptıkları çalışmada, kurumsal sosyal sorumluluk performansı daha yüksek olarak algılanan kurumların potansiyel çalışanlar açısından daha cazip (çekici) olduğu ve kurumsal sosyal performans ile potansiyel çalışanların iş arama, iş görüşmesi yapma olasılığ ve iş teklifini kabul etme olasılığı arasında 
pozitif ilişki olduğu bulgularına ulaşmışlardır. Jain (2013), çalışanlardan oluşan bir örneklem kullanarak yaptığı çalışmada, kurumsal sosyal sorumluluğun, işletmede kalma niyetinin ve motivasyonun işveren markası algısıyla pozitif ilişkili olduğunu bulmuştur. Ibrahim (2017), yüksek lisans öğrencilerinden oluşan bir örneklem kullanarak yaptığı çalışmasında, kurumsal sosyal sorumluluk faaliyetleri ile işveren çekiciliği arasındaki ilişkiyi ve bu ilişkide bireysel gelir seviyesinin moderatör (aracı) etkisinin olup olmadığını araştırmıştır. Çalışmada, sosyal sorumlu organizasyonlar ile işveren markası çekiciliği arasında güçlü bir ilişki olduğu ve bu ilişkide bireysel gelirin aracı rolü olmadığı bulgularına ulaşılmıştır. Klimkiewicz ve Oltra (2017), Y kuşağı iş arayanların kurumsal sosyal sorumluluğa ilişkin tutumlarının, kurumsal sosyal sorumluluk bazlı işveren markası üzerindeki etkisini araştırmak amacıyla, Polonya'da iki üniversitede okuyan öğrencilerden oluşan bir örneklem kullanarak yaptıkları çalışmalarında, katılımcıların kurumsal sosyal sorumluluğa ilişkin pozitif tutumlarının, kurumsal sosyal sorumluluk bazlı işveren markası algılarını arttırdığı bulgusuna ulaşmışlardır. Tkalac Vercic ve Sincic Coric (2018), üniversite öğrencilerinin algılanan kurum itibarı ile kurumsal sosyal sorumluluk ve işveren markası algıları arasındaki ilişkileri araştırmışlardır. Çalışmada, bu üç değişken arasında pozitif ilişki olduğu ve katılımcıların yüksek itibarlı olarak ifade ettikleri kurumlar için kurumsal sosyal sorumluluk ve işveren markası algılarının da yüksek olduğu bulgularına ulaşılmıştır. Hinson vd. (2018), lisans ve yüksek lisans öğrencilerinden oluşan bir örneklem kullanarak yaptıkları çalışmada, katılımcıların kurumsal sosyal sorumluluk algılarının işveren çekiciliği üzerindeki etkisini araştırmışlar ve kurumsal sosyal sorumluluk algısının işveren çekiciliğini pozitif etkilediği bulgusuna ulaşmışlardır.

Ulusal literatürde, kurumsal sosyal sorumluluk faaliyetleri ile işveren markası algısı arasındaki ilişkileri inceleyen sadece bir çalışmaya rastlanılmıştır. Söz konusu çalışma, Ersoy ve Akşehirli (2015) tarafindan yapılmıştır. Ersoy ve Akşehirli (2015) üniversite öğrencilerinden oluşan bir örneklem kullanarak yaptıkları çalışmalarında, kurumsal sosyal sorumluluk faaliyetlerinin bir kurumun çekiciliğini arttırıp artırmadığını ve işveren çekiciliği üzerinde hangi kurumsal sosyal sorumluluk boyutlarının etkisinin daha fazla olduğunu araştırmışlardır. Araştırmacılar, bir bütün olarak kurumsal sosyal sorumluluk faaliyetlerinin işveren çekiciliği üzerinde pozitif etkisinin olduğunu ve kurumsal sosyal sorumluluğun işveren çekiciliğini etkileyen en önemli boyutlarının çalışanlarla ilişkiler, toplumla ilişkiler ve ürün sürdürülebilirliği olduğunu bulmuşlardır.

\section{Metodoloji}

\subsection{Araştırmanın Amacı, Kapsamı ve Önemi}

İşveren markasıyla ilgili ampirik çalışmaların, genel olarak, mevcut durumda belirli bir işletmede çalışanlar (örneğin bkz.: Davies, 2008; Jain, 2013; Çiftçioğlu, 2014; Reis ve Braga, 2016; Saruhan Yalça, 2017; Dursun ve Eriş, 2018; Albayrak vd., 2019) ile potansiyel çalışanlar (örneğin bkz.: Greening ve Turban, 2000; Gözen, 2006; Wilden vd., 2010; Erkanl1 vd., 2015; Narcıkara vd., 2016; Klimkiewicz ve Oltra, 2017; Tkalac Vercic ve Sincic Coric, 2018; Kahveci, 2018; Saylan ve Eroğlu, 2019) üzerine yapıldığı görülmektedir. Eğitim hayatlarının son aşamasında olmaları ve iş hayatına atılacak olmaları nedeniyle, üniversite öğrencileri başlıca potansiyel çalışanlardır ve üniversite öğrencilerinin iş başvurusu yapacakları kurum tercihlerinde öne çıkan önemli faktörlerden biri işveren markası algısıdır. Dolayısıyla bu çalışma üniversite öğrencileri üzerine yapılmıştır.

Çalışmanın amacı, üniversite öğrencilerinin kurumsal sosyal sorumluluk algı düzeylerinin işveren markası algısı ve alt boyutları üzerindeki etkilerini incelemektir. Bu kapsamda, araştırmanın evrenini, Bursa Uludağ Üniversitesi İktisadi ve İdari Bilimler Fakültesi'nin İktisat, Maliye, Çalışma Ekonomisi ve Endüstri İlişkileri (ÇEKO), İşletme, Uluslararası İlişkiler, Ekonometri ve Siyaset Bilimi ve Kamu Yönetimi bölümlerinde okuyan üçüncü ve dördüncü sınıf öğrencileri oluşturmaktadır. Araştırmanın kapsamına sadece üçüncü ve dördüncü sınıflar ile beşinci ve üzeri sınıfların dahil edilmesinin nedeni, bu öğrencilerin mezuniyete daha yakın olmaları ve mezuniyet sonrası iş başvurusu yapacakları olası kurum veya işletmeler hakkında daha net fikirlere sahip olabilecekleri varsayımıdır.

$\mathrm{Bu}$ çalışmanın bulguları, potansiyel çalışanların bir işletmeye iş başvurusu yaparken hangi özellikleri aradıkları ve işletmelerin kurumsal sosyal sorumluluk faaliyetlere ilişkin algının işveren markası algısı üzerinde bir etkisinin olup olmadığı konusunda literatüre bir katkı sağlayacaktır. Söz konusu bulgular, işletmelerin işveren markası oluşturma, yetenekli adayları kendilerine çekme ve mevcut çalışanları ellerinde tutma çabaları açısından ilgili taraflara faydalı olabilecektir. Mevcut ve potansiyel adayların beklentilerini bilen kurumlar, işveren markalarını daha iyi yönetebileceklerdir.

\subsection{Araştırmanın Yöntemi, Verilerin Toplanması ve Analizi}

Araştırma için gerekli veriler anket tekniği kullanılarak toplanmıştır. Kolayda örnekleme yöntemiyle, 933 öğrenciye anket uygulanmış, 64 anket eksik doldurulması nedeniyle analize dahil edilmemiş, dolayısıyla 869 anket verisi değerlendirmeye alınmıştır. Söz konusu anketin uygulanması, 4 Mart - 15 Mart 2019 tarihleri arasında gerçekleştirilmiştir.

Veri toplama aracı olarak kullanılan anket, üç bölümden oluşmaktadır. Birinci bölümde, katılımcıların cinsiyeti, yaşı, okudukları bölüm, akademik seviyesi (sınıfi), öğretim şekli (örgün ve ikinci öğretim), iş tecrübesi gibi demografik bilgilerine yönelik sorular yer almaktadır.

İkinci bölümde, işveren markası algı düzeylerini belirlemek amacıyla Berthon vd. (2005) tarafindan geliştirilen işveren markası ölçeği kullanılmıştır. Çeşitli ulusal ve yabancı çalışmalarda da kullanılan bu ölçek (örneğin, Roy, 2008; Arachchige ve Robertson, 2011; Sivertzen vd., 2013; Alnıaçık vd., 2014; Narcıkara vd., 2016; Ardıç ve Gündoğmuş, 
2016; Tkalac Vercic ve Sincic Coric, 2018) toplam 25 maddeden ve beş alt boyuttan (faktörden) oluşmaktadır. Bu boyutlar; sosyal değer, ekonomik değer, başvuru değeri, gelişim değeri ve fayda değeridir. Sosyal değer, işverenin sunmuş olduğu mutlu ve eğlenceli çalışma ortamını; ekonomik değer, iyi bir ücret ve terfi imkânının olup olmadığını; başvuru değeri, işverenin müşteri odaklılığı ve bilgileri uygulamaya aktarabilme firsatını sağlamasını; gelişim değeri, çalışanlara yönelik eğitim ve kariyer olanaklarını ve fayda değeri, ürün ve hizmetlerin kaliteli ve yenilikçi olmasını ve işverenin sağladığı yaratıcı çalışma ortamını ifade etmektedir. Orijinalinde yedili Likert tipi ölçek kullanılmış iken, bu çalışmada, diğer ölçekle de (kurumsal sosyal sorumluluk ölçeği) uyumlu olması için, beşli Likert tipi ölçek kullanılmıştır. Bu kapsamda, her bir madde, "1=Hiç önemli değil”, "5=Çok önemli”" şeklinde kodlanmıştır.

Üçüncü bölümde, öğrencilerin kurumsal sosyal sorumluluk algı düzeylerini belirlemek için, Carroll (1991)'un KSS boyutlarını karakterize etmek amacıyla önerdiği ifadelerden oluşan bir ölçek kullanılmıştır. Carroll (1979, 1991), KSS'nin boyutlarını; ekonomik, yasal, etik ve gönüllü sorumluluklar olmak üzere dörde ayırmış ve her bir KSS boyutuyla ilgili beş ifade vermiştir. Dolayısıyla kurumsal sosyal sorumluluk algısını değerlendirmek için toplam 20 ifadeden oluşan bu ölçek, beşli Likert tipinde, "1= Hiç Katılmıyorum”, “5=Tamamen Katılıyorum” şeklinde kodlanmıştır.

Demografik özellikler ve iki ayrı ölçekten oluşan anket, 30 kişiden oluşan bir öğrenci grubuna yaptırılmış, geri dönüşlere bağlı olarak küçük düzeltmeler sonucunda ankete son hali verilmiştir.

Verilerin analizinde, tanımlayıcı istatistikler ve korelasyon analizi ile kurumsal sosyal sorumluluk algı düzeylerinin işveren markası algısı ve alt boyutları üzerindeki etkilerini değerlendirmek amacıyla regresyon analizi kullanılmıştır.

\section{Bulgular}

\subsection{Katılımcıların Demografik Özellikleri}

Katılımcıların demografik bilgileri incelendiğinde, katılımcıların \%60,6'sının kadın ve 39,4'ünün erkek, \%53,5'inin 21 22 yaş aralığında ve \%54,2'sinin birinci eğitim öğrencisi olduğu görülmektedir. Katılımcıların okudukları bölüm açısından orantılı bir dağılım söz konusu olup, katılımcıların \% 16,1'i İşletme bölümünde, \%16,1'i Ekonometri bölümünde ve \%15,9’u Maliye bölümünde okurken, İktisat, Uluslararası İlişkiler, ÇEKO ile Siyaset Bilimi ve Kamu Yönetimi bölümlerinde okuyanların toplam oranı da \%51,9'dur. Katılımcıların \%41,7'si üçüncü sınıfta, \%48'i dördüncü sınıfta okurken, kalan \%10,4’ü beşinci veya üzeri sınıflarda okumaktadır.

Tablo 1. Katılımcıların Demografik Özellikleri

\begin{tabular}{|c|c|c|c|c|c|}
\hline Cinsiyet & Frekans & $\%$ & Öğretim Şekli & Frekans & $\%$ \\
\hline Kadın & 527 & 60,6 & Örgün Öğretim & 471 & 54,2 \\
\hline Erkek & 342 & 39,4 & İkinci Öğretim & 398 & 45,8 \\
\hline Toplam & 869 & 100,0 & Toplam & 869 & 100,0 \\
\hline Yaş & Frekans & $\%$ & Sinıf & Frekans & $\%$ \\
\hline 20 yaş ve altı & 59 & 6,8 & 3.sinif & 362 & 41,7 \\
\hline $21-22$ yaş & 465 & 53,5 & 4.sinif & 417 & 48,0 \\
\hline $23-24$ yaş & 265 & 30,5 & 5.sinıf ve üzeri & 90 & 10,4 \\
\hline 25 yaş ve üzeri & 80 & 9,2 & Toplam & 869 & 100,0 \\
\hline Toplam & 869 & 100,0 & & & \\
\hline Bölüm & Frekans & $\%$ & İş Tecrübesi & Frekans & $\%$ \\
\hline İktisat & 106 & 12,2 & İş tecrübesi yok & 275 & 31,6 \\
\hline Maliye & 138 & 15,9 & 1 y1ldan az & 306 & 35,2 \\
\hline İşletme & 140 & 16,1 & $1-2$ y1l aras 1 & 159 & 18,3 \\
\hline Uluslararası İliş. & 131 & 15,1 & $3-4$ yıl arası & 68 & 7,8 \\
\hline Ekonometri & 140 & 16,1 & 5 yıl ve üzeri & 61 & 7,0 \\
\hline ÇEKO & 108 & 12,4 & Toplam & 869 & 100,0 \\
\hline Siyaset B. ve K.Y. & 106 & 12,2 & Aylık Ort. Gelir & Frekans & $\%$ \\
\hline Toplam & 869 & 100,0 & $1-2.020 \mathrm{TL}$ & 163 & 18,8 \\
\hline Sektör & Frekans & $\%$ & $2.021-5.000 \mathrm{TL}$ & 429 & 49,4 \\
\hline Kamu & 386 & 44,4 & $5.001-7.500 \mathrm{TL}$ & 169 & 19,4 \\
\hline Özel & 483 & 55,6 & $7.501-10.000 \mathrm{TL}$ & 65 & 7,5 \\
\hline Toplam & 869 & 100,0 & 10.001TL ve üzeri & 43 & 4,9 \\
\hline & & & $\begin{array}{l}\text { Toplam } \\
\end{array}$ & 869 & 100,0 \\
\hline
\end{tabular}

Katılımcıların \%31,6'sı iş tecrübesi olmadığını ve \%55,6'sı da mezuniyet sonrası özel sektörde çalışmak istediğini ifade etmiştir. Ailenin aylık ortalama gelir düzeyi açısından, katılımcıların \%49,4'ü ailesinin aylık ortalama gelirinin 2.021 TL - 5.000 TL arasında olduğunu ifade ederken, sadece \%4,9'u 10.001 TL ve üzeri olduğunu ifade etmiştir. Katılımcıların demografik bilgileri Tablo 1'de görülmektedir. 


\subsection{Faktör ve Güvenirlik Analizleri}

\subsection{1. İşveren Markası Ölçeğine İlişkin Geçerlilik ve Güvenirlik Analizleri}

İngilizceden Türkçeye uyarlanan işveren markası ölçeğinin yapı geçerliliğini test etmek amacıyla keşfedici (açımlayıcı) faktör analizi yapılmış, ardından ölçeğin güvenirlik (iç tutarlılık) analizi yapılmıştır. Öncelikle Kaiser-Meyer-Olkin (KMO) ve Bartlett testi yapılarak veri setinin faktör analizine uygunluğu incelenmiştir. KMO katsayısı $(0,938)$ ve Bartlett testi değerleri $(\chi 2=9.949,120, \mathrm{df}=300, \mathrm{p}=0,000)$ verilerin faktör analizi için uygun olduğunu göstermiştir.

Temel Bileşenler Analizi (Principal Components Analysis, PCA) ve "Varimax Rotasyon" yöntemiyle yapılan keşfedici faktör analizi sonucunda, ölçekteki maddelerin dört boyut (faktör) altında toplandığ 1 ve maddelerin faktör yükü değerlerinin 0,395 - 0,797 aralığında değişim gösterdiği görülmüştür. Bir maddenin birden fazla faktöre verdiği faktör yükler arasındaki farkın minimum 0,10 olması gerektiğinden (Karaman vd., 2017), bu koşulu sağlamayıp iki faktörün de altında yer alan dört madde aşamalı olarak analizden çıkarılmış ve sonuçta kalan maddeler üç boyut altında toplanmıştır. Dokuz maddenin toplandığ 1 birinci faktör "başvuru ve fayda değeri” boyutu, yedi maddenin toplandığ 1 ikinci faktör "sosyal ve gelişim değeri” boyutu ve beş maddenin toplandığı üçüncü faktör ise "ekonomik değer" boyutu olarak adlandırılmıştır. Tablo 2'de keşfedici faktör analizinin sonuçları kapsamında, faktörlere yüklenen maddeler ve faktör yükleri görülmektedir.

Tablo 2. İşveren Markası Ölçeğinde Faktörler ve Faktör Yükleri

\begin{tabular}{|c|c|c|c|}
\hline Madde & Faktör 1 & Faktör 2 & Faktör 3 \\
\hline $\begin{array}{l}\text { Daha önce çalıştığınız işlerde öğrendiğiniz/edindiğiniz bilgi } \\
\text { ve tecrübeleri kullanma firsatının verilmesi }\end{array}$ & 0,772 & & \\
\hline $\begin{array}{l}\text { Öğrendiğiniz/edindiğiniz bilgi ve tecrübeleri, iş } \\
\text { arkadaşlarınıza öğretme ve aktarma firsatının verilmesi }\end{array}$ & 0,761 & & \\
\hline $\begin{array}{l}\text { İşletmenin/kurumun, yenilikçi mal ve hizmetler üretiyor } \\
\text { olması }\end{array}$ & 0,744 & & \\
\hline $\begin{array}{l}\text { İşletmenin/kurumun yardımsever olması ve kazandıklarının } \\
\text { bir kısmını topluma geri vermesi }\end{array}$ & 0,711 & & \\
\hline $\begin{array}{l}\text { İşletmenin/kurumun, yüksek kalitede mal ve hizmetler } \\
\text { üretiyor olmas1 }\end{array}$ & 0,676 & & \\
\hline $\begin{array}{l}\text { Çalıştığınız işletmede/kurumda departmanlar arası tecrübe } \\
\text { edinme imkanının olması }\end{array}$ & 0,666 & & \\
\hline $\begin{array}{l}\text { İşvereninizin işle ilgili yeni uygulamalara açık, yenilikçi ve } \\
\text { ileri görüş̧ı̈ olması }\end{array}$ & 0,641 & & \\
\hline $\begin{array}{l}\text { Yaratıcılığınıza değer verilmesi ve yaratıcıllğınızdan } \\
\text { yararlanılması }\end{array}$ & 0,626 & & \\
\hline Çalıştığınız işletmenin/kurumun müşteri-odaklı olması & 0,605 & & \\
\hline Üstlerinizle iyi ilişkiler içinde olmanız & & 0,788 & \\
\hline İş arkadaşlarınızla iyi ilişkiler içinde olmanız & & 0,773 & \\
\hline Sizi destekleyen ve cesaretlendiren iş arkadaşlarınızın olması & & 0,602 & \\
\hline $\begin{array}{l}\text { O işletmede çalışıyor olmanın kendinize olan güveninizi } \\
\text { artırması }\end{array}$ & & 0,578 & \\
\hline O işletmede çalışıyor olmanın sizi iyi hissettirmesi & & 0,531 & \\
\hline Yönetim tarafindan kabul görmeniz ve takdir edilmeniz & & 0,504 & \\
\hline Kariyer hedefleriniz doğrultusunda size tecrübe kazandırmas 1 & & 0,499 & \\
\hline $\begin{array}{l}\text { Maaş/ücret dışında; ikramiye, prim, yemek ücreti, bireysel } \\
\text { emeklilik planı gibi cazip ek maddi haklar sunması }\end{array}$ & & & 0,707 \\
\hline Ortalamanın üzerinde bir maaş/ücret olması & & & 0,676 \\
\hline Çalıştığınız işletmede/kurumda iş güvencesinin olması & & & 0,631 \\
\hline Mutlu bir çalışma ortamının olması & & & 0,564 \\
\hline Yükselme ve atama firsatlarının iyi olması & & & 0,459 \\
\hline
\end{tabular}

Tablo 3 'te, her bir faktörün özdeğer katsayıları, toplam varyansın \% kaçını açıkladığı ile kümülatif varyans değerleri yer almaktadır. Toplam 21 maddeden oluşan üç faktörün işveren markası algısını açıklama gücü \% 53,63 olmuştur. İşveren markası ölçeğinin tamamına ve alt boyutlarına ilişkin Cronbach Alpha katsayıları Tablo 3'te yer almaktadır. Cronbach Alpha güvenirlik katsayıları ( $\alpha$ ), Faktör 1 için 0,898, Faktör 2 için 0,85, Faktör 3 için 0,667 ve tüm ölçek için 0,917 olarak hesaplanmıştır. Bu değerlere bakılarak ölçeğin oldukça güvenilir olduğu söylenebilir. 
Anbar, D., Çiftçioğlu, B., A., Anbar, A. / Journal of Yasar University, 2020, 15/58, 221-235

Tablo 3. İşveren Markası Ölçeğinde Faktörlerin Özdeğer, Varyans ve Kümülatif Varyans Değerleri ile Güvenirlik Katsayıları

\begin{tabular}{|c|c|c|c|c|c|}
\hline Faktör & $\begin{array}{c}\text { Madde } \\
\text { Sayısı }\end{array}$ & Özdeğer & $\begin{array}{c}\text { Varyans } \\
(\%) \\
\end{array}$ & $\begin{array}{c}\text { Kümülatif } \\
\text { Varyans }(\%)\end{array}$ & $\alpha$ \\
\hline Faktör 1 (Başvuru ve Fayda Değeri) & 9 & 8,148 & 24,840 & 24,840 & 0,898 \\
\hline Faktör 2 (Sosyal ve Gelişim Değeri) & 7 & 1,856 & 17,026 & 41,866 & 0,850 \\
\hline Faktör 3 (Ekonomik Değer) & 5 & 1,259 & 11,768 & 53,634 & 0,667 \\
\hline Tüm Ölçek & 21 & & & & 0,917 \\
\hline
\end{tabular}

\subsubsection{Kurumsal Sosyal Sorumluluk Ölçeğine İlişkin Geçerlilik ve Güvenirlik Analizleri}

Carroll (1991)'un kurumsal sosyal sorumluluk boyutlarını (ekonomik, yasal, etik ve gönüllü sorumluluklar) karakterize etmek amacıyla önerdiği 20 ifadenin Türkçeye çevrilmesiyle oluşturulan ve katılımciların kurumsal sosyal sorumluluk algılarını ölçmeye yönelik ölçeğin yapı geçerliliğini test etmek amacıyla keşfedici faktör analizi yapılmıştır. KMO (0,903) ve Bartlett testi sonuçları $(\chi 2=6.124,023, \mathrm{df}=190, \mathrm{p}=0,000)$ veri setinin faktör analizine uygun olduğunu göstermektedir.

Çıkarım yöntemi olarak "Temel Bileşenler Analizi" ve rotasyon yöntemi olarak "Varimax" kullanılarak gerçekleştirilen faktör analizi sonucunda, ölçekteki 20 madde 4 faktör altında toplanmıştır. Faktör yükü değerleri 0,408 ila 0,856 aralığında değişen maddelerden birinin her iki faktörün de altında toplandığı görülmüş, bu nedenle analizden çıkarılarak faktör analizi tekrarlanmıştır. Analiz sonrasında, bir maddenin daha, yük değerleri arasındaki fark 0,10'dan küçük olacak şekilde, iki faktör altında yer aldığı görülmüş ve bu madde de analizden çıkarılarak faktör analizi tekrarlanmıştır. İki maddenin çıkarılmasıyla kalan 18 madde dört faktör altında toplanmıştır. Beş maddeden oluşan birinci faktör "gönüllü sorumluluk" boyutu; dört maddeden oluşan ikinci faktör "yasal sorumluluk" boyutu; beş maddeden oluşan üçüncü faktör "etik sorumluluk" boyutu ve dört maddeden oluşan dördüncü faktör ise "ekonomik sorumluluk" boyutu olarak adlandırılmıştır. Tablo 4’te kurumsal sosyal sorumluluk ölçeğine ilişkin faktör analizinin sonuçları yer almaktadır.

Tablo 4. Kurumsal Sosyal Sorumluluk Ölçeğinde Faktörler ve Faktör Yükleri

\begin{tabular}{|c|c|c|c|c|}
\hline Madde & Faktör 1 & Faktör 2 & Faktör 3 & Faktör 4 \\
\hline $\begin{array}{l}\text { Bir işletme, özel ve kamu eğitim kurumlarına destek } \\
\text { vermelidir. }\end{array}$ & 0,859 & & & \\
\hline $\begin{array}{l}\text { İşletme yöneticileri ve çalışanları, yardım ve hayır } \\
\text { faaliyetlerine katılmalıdır. }\end{array}$ & 0,813 & & & \\
\hline $\begin{array}{l}\text { Bir işletme; resim, heykel, müzik, şiir, tiyatro, dans gibi } \\
\text { sanat dallarını desteklemelidir. }\end{array}$ & 0,801 & & & \\
\hline $\begin{array}{l}\text { Bir işletme, toplumun "yaşam kalitesini" artıran projelere } \\
\text { gönüllü olarak destek vermelidir. }\end{array}$ & 0,800 & & & \\
\hline $\begin{array}{l}\text { Bir işletme; toplumun, toplumsal sorun ve problemlerin } \\
\text { çözümüne katkıda bulunma veya yardım etme } \\
\text { beklentisine uygun bir şekilde faaliyet göstermelidir. }\end{array}$ & 0,471 & & & \\
\hline Bir işletme; kanun, tüzük ve yönetmeliklere uymalıdır. & & 0,824 & & \\
\hline $\begin{array}{l}\text { Bir işletme, kanunlara saygılı bir "kurumsal vatandaş" } \\
\text { olmalıdır. }\end{array}$ & & 0,791 & & \\
\hline $\begin{array}{l}\text { Bir işletme, kanunlara ve devletin beklentilerine uygun } \\
\text { şekilde faaliyet göstermelidir. }\end{array}$ & & 0,783 & & \\
\hline $\begin{array}{l}\text { Başarılı bir işletme, "yasal yükümlülüklerini" yerine } \\
\text { getiren bir işletmedir. }\end{array}$ & & 0,659 & & \\
\hline $\begin{array}{l}\text { Bir işletmenin amaçlarına ulaşmak için etik normlardan } \\
\text { ödün vermesi önlenmelidir. }\end{array}$ & & & 0,771 & \\
\hline $\begin{array}{l}\text { Ahlaki veya etik açıdan beklenen şeyleri yapan bir } \\
\text { işletme, iyi bir kurumsal vatandaştır. }\end{array}$ & & & 0,692 & \\
\hline $\begin{array}{l}\text { Bir işletme, etik davranmanın, sadece kanun ve } \\
\text { yönetmeliklere uymanın ötesinde bir şey olduğunu } \\
\text { bilmelidir. }\end{array}$ & & & 0,591 & \\
\hline
\end{tabular}




\begin{tabular}{|c|c|c|}
\hline $\begin{array}{l}\text { Bir işletme, toplum tarafindan benimsenen yeni veya } \\
\text { zaman içinde değişen etik/ahlaki normları tanımalı ve } \\
\text { bunlara saygı göstermelidir. }\end{array}$ & 0,538 & \\
\hline $\begin{array}{l}\text { Bir işletme, faaliyetini sürdürürken en azından asgari } \\
\text { yasal yükümlülüklerini yerine getirmelidir. }\end{array}$ & 0,437 & \\
\hline $\begin{array}{l}\text { Bir işletme, güçlü bir rekabetçi pozisyona sahip olmalı ve } \\
\text { bunu sürdürmelidir. }\end{array}$ & & 0,737 \\
\hline $\begin{array}{l}\text { Bir işletme, hisse (pay) başına kârını maksimize edecek } \\
\text { şekilde çalışmalıdır. }\end{array}$ & & 0,733 \\
\hline Bir işletme, mümkün olduğunca kârlı olmalıdır. & & 0,672 \\
\hline $\begin{array}{l}\text { Bir işletme, yüksek düzeyde faaliyet verimliliğine } \\
\text { (girdi/çıktı oranına) sahip olmalı ve bunu sürdürmelidir. }\end{array}$ & & 0,648 \\
\hline
\end{tabular}

Kurumsal sosyal sorumluluk ölçeğinde, birinci faktör toplam varyansın yaklaşık olarak \%17,75'ini, ikinci faktör \%15,70'ini, üçüncü faktör \%12,61'ini ve dördüncü faktör \%12,26'sını açıklamaktadır. Bu dört faktör toplam varyansın \%58,31'ini açıklamaktadır. Tablo 5, her bir faktörün özdeğer ve varyansları ile Cronbach Alpha güvenirlik katsayılarını göstermektedir. Kurumsal sosyal sorumluluk ölçeğinin alt boyutları ve geneli için hesaplanan Cronbach Alpha güvenirlik katsayıları $(\alpha)$ ölçeğin güvenirliğinin yeterli ve yüksek olduğunu göstermektedir.

Tablo 5. Kurumsal Sosyal Sorumluluk Ölçeğinde Faktörlerin Özdeğer, Varyans ve Kümülatif Varyans Değerleri ile Güvenirlik Katsayıları

\begin{tabular}{|l|c|c|c|c|c|}
\hline Faktör & $\begin{array}{c}\text { Madde } \\
\text { Sayısı }\end{array}$ & Özdeğer & $\begin{array}{c}\text { Varyans } \\
(\boldsymbol{\%})\end{array}$ & $\begin{array}{c}\text { Kümülatif } \\
\text { Varyans (\%) }\end{array}$ & $\boldsymbol{\alpha}$ \\
\hline Faktör 1 (Gönüllü Sorumluluk) & 5 & 5,790 & 17,746 & 17,746 & 0,858 \\
\hline Faktör 2 (Yasal Sorumluluk) & 4 & 1,917 & 15,697 & 33,443 & 0,826 \\
\hline Faktör 3 (Etik Sorumluluk) & 5 & 1,620 & 12,608 & 46,050 & 0,679 \\
\hline Faktör 4 (Ekonomik Sorumluluk) & 4 & 1,169 & 12,260 & 58,310 & 0,696 \\
\hline \multicolumn{1}{|r|}{ Tüm Ölçek } & 18 & & & & 0,867 \\
\hline
\end{tabular}

\subsection{Katılımcıların İşveren Markası ve Kurumsal Sosyal Sorumluluk Algı Düzeylerinin Değerlendirilmesi}

Katılımcıların işveren markası ölçeğinin alt boyutları bazında ve tümü için verdikleri yanıtların minimum, maksimum, ortalama ve standart sapma değerleri Tablo 6'da yer almaktadır. Alt boyutlar itibariyle, başvuru ve fayda değeri boyutunun ortalamas 13,77, sosyal ve gelişim değeri boyutunun ortalamas 1,11 ve ekonomik değer boyutunun ortalaması 4,31'dir. Dolayısıyla potansiyel adayların iş başvurusu yaparken bir işletmede/kurumda aradıkları veya önem verdikleri özelliklerin başında maaş/ücret, iş güvencesi, yükselme/atama firsatları, maddi yan haklar gibi ekonomik özellikler gelmektedir. Bunu, iyi bir çalışma ortamı ve kariyer gelişimi için tecrübe edinme gibi özellikleri içinde barındıran sosyal ve gelişim değeri izlemektedir. İşletmenin/kurumun kaliteli ve yenilikçi mal/hizmetler üretiyor olması, müşsteri odaklı olması, yardımsever olması ve kazandıklarının bir kısmını topluma geri vermesi, daha önce edinilen bilgi ve tecrübelerin diğer iş arkadaşlarına aktarma firsatı vermesi gibi unsurları içinde barındıran başvuru ve fayda değeri boyutu ise potansiyel adayların en az önem verdikleri boyuttur. İşveren markası ölçeğine verilen yanıtlar bir bütün olarak değerlendirildiğinde, ortalama değerin 4,01 ve standart sapma değerinin 0,52 olduğu görülmektedir. Bu değerler, üniversite öğrencilerinin işveren markası algılarının genel olarak yüksek olduğu, diğer bir deyişle, işveren markası çekiciliğini oluşturan özelliklere verdikleri önem derecesinin yüksek olduğu şeklinde yorumlanabilir.

Tablo 6. İşveren Markasının Alt Boyutları ve Tümü için Ortalama ve Standart Sapma Değerleri

\begin{tabular}{|l|c|c|c|c|}
\hline İşveren Markası Ölçeği & Minimum & Maksimum & Ortalama & S. Sapma \\
\hline Başvuru ve Fayda Değeri Boyutu & 1,11 & 5,00 & 3,7706 & 0,70012 \\
\hline Sosyal ve Gelişim Değeri Boyutu & 1,14 & 5,00 & 4,1052 & 0,57542 \\
\hline Ekonomik Değer Boyutu & 2,00 & 5,00 & 4,3112 & 0,46828 \\
\hline Tüm Ölçek & 1,81 & 5,00 & 4,0108 & 0,51686 \\
\hline n=869
\end{tabular}


Katılımcıların kurumsal sosyal sorumluluk ölçeğine verdikleri yanıtlar değerlendirildiğinde, verilen yanıtların ortalama değerinin 4,04 ve standart sapmasının 0,46 olduğu görülmektedir. Bu değerler, katılımcıların kurumsal sorumluluk alg1 düzeylerinin yüksek olduğu şeklinde yorumlanabilir. Alt boyutlara bakıldığında, katılımcıların alg1 düzeylerinin en yüksek olduğu boyut, 4,26 ortalama değeriyle yasal sorumluluk boyutudur. Katılımcıların algı düzeylerinin en düşük olduğu boyut ise, 3,93 ortalamayla gönüllü sorumluluk boyutudur. Dolayısıyla katılımcılar işletmelerin öncelikli olarak yasalara uygun faaliyette bulunmalarını istemekte, daha sonra, ekonomik, etik ve gönüllü sorumluluklarını yerine getirmelerini beklemektedir. Tablo 7'de kurumsal sosyal sorumluluk ölçeğinin geneli ve alt boyutları bazında verilen yanıtların maksimum, minimum, ortalama ve standart sapma değerleri yer almaktadır.

Tablo 7. Kurumsal Sosyal Sorumluluk Ölçeğinin Alt Boyutları ve Tümü için Ortalama ve Standart Sapma Değerleri

\begin{tabular}{|l|c|c|c|c|}
\hline İşveren Markası Ölçeği & Minimum & Maksimum & Ortalama & S. Sapma \\
\hline Ekonomik Sorumluluk Boyutu & 1,00 & 5,00 & 4,0170 & 0,55676 \\
\hline Yasal Sorumluluk Boyutu & 1,00 & 5,00 & 4,2569 & 0,63098 \\
\hline Etik Sorumluluk Boyutu & 1,00 & 5,00 & 3,9993 & 0,57164 \\
\hline Gönüllü Sorumluluk Boyutu & 1,00 & 5,00 & 3,9261 & 0,72138 \\
\hline Tüm Ölçek & 1,50 & 5,00 & 4,0401 & 0,46366 \\
\hline
\end{tabular}

\subsection{Korelasyon Analizi}

Regresyon analizine geçmeden önce, bağımlı ve bağımsız değişenler arasındaki ilişkilerin derecesini ve yönünü ortaya koymak amacıyla yapılan Pearson korelasyon analizinin sonuçları Tablo 8'te yer almaktadır. Tabloda görüldüğü gibi, bütün değişkenler arasında, diğer bir ifadeyle, işveren markasının alt boyutları ile kurumsal sosyal sorumluluk algısının alt boyutları arasında, pozitif yönde ve $p<0,01$ düzeyinde anlamlı ilişkiler vardır. Tablo 8 incelendiğinde, başvuru ve fayda değeri ile sosyal ve gelişim değeri arasında pozitif yönde ve yüksek düzeyde $(r=0,709, p<0,01)$ ve başvuru ve fayda değeri ile ekonomik değer boyutu arasında pozitif yönde ve orta düzeyde $(r=0,381, p<0,01)$ bir ilişkinin olduğu görülmektedir. İşveren markası algısı ile kurumsal sosyal sorumluluk algısının alt boyutları arasındaki ilişkilere bakıldığında, en yüksek ilişkinin başvuru ve fayda değeri ile gönüllü sorumluluk boyutları arasında olduğu (r=0,503, $\mathrm{p}<0,01)$ ve en düşük ilişkinin de ekonomik değer boyutu ile ekonomik sorumluluk boyutu arasında $(\mathrm{r}=0,269, \mathrm{p}<0,01)$ olduğu görülmektedir.

Tablo 8. İşveren Markası Ölçeğinin Alt Boyutları ile Kurumsal Sosyal Sorumluluk Ölçeğinin Alt Boyutları Arasındaki Korelasyon Analizi Sonuçları

\begin{tabular}{|l|c|c|c|c|c|c|c|}
\hline & $\mathbf{1}$ & $\mathbf{2}$ & $\mathbf{3}$ & $\mathbf{4}$ & $\mathbf{5}$ & $\mathbf{6}$ & $\mathbf{7}$ \\
\hline $\begin{array}{l}\text { 1. Başvuru ve Fayda } \\
\text { Değeri }\end{array}$ & 1 & & & & & & \\
\hline $\begin{array}{l}\text { 2. Sosyal ve Delişim } \\
\text { Değeri }\end{array}$ & $0,709^{* *}$ & 1 & & & & & \\
\hline 3. Ekonomik Değer & $0,381^{* *}$ & $0,487^{* *}$ & 1 & & & & \\
\hline $\begin{array}{l}\text { 4. Gönüllüi } \\
\text { Sorumluluklar }\end{array}$ & $0,503^{* *}$ & $0,458^{* *}$ & $0,268^{* *}$ & 1 & & & \\
\hline $\begin{array}{l}\text { 5. Yasal } \\
\text { Sorumluluklar }\end{array}$ & $0,326^{* *}$ & $0,378^{* *}$ & $0,273^{* *}$ & $0,400^{* *}$ & 1 & & \\
\hline $\begin{array}{l}\text { 6. Etik } \\
\text { Sorumluluklar }\end{array}$ & $0,347^{* *}$ & $0,360^{* *}$ & $0,207^{* *}$ & $0,444^{* *}$ & $0,514^{* *}$ & & 1 \\
\hline $\begin{array}{l}\text { 7. Ekonomik } \\
\text { Sorumluluklar }\end{array}$ & $0,282^{* *}$ & $0,299^{* *}$ & $0,269^{* *}$ & $0,329^{* *}$ & $0,364^{* *}$ & $0,308^{* *}$ & 1 \\
\hline
\end{tabular}

$* * \mathrm{p}<0,01$ düzeyinde anlamlıdır.

\subsection{Regresyon Analizi}

Katılımcıların kurumsal sosyal sorumluluk algı düzeylerinin işveren markası algı düzeyleri üzerinde bir etkisinin olup olmadığını test etmek amacıyla, çoklu doğrusal regresyon analizleri yapılmıştır. Bu analizlerde, işveren markası algısının geneli ile alt boyutları bağımlı değişken olarak, kurumsal sosyal sorumluluk algısının alt boyutları ise bağımsız değişken olarak alınmıştır. Dolayısıyla dört regresyon modeli oluşturulmuştur. Bu modeller aşağıdaki şekilde gösterilebilir:

$$
\begin{aligned}
& \text { YBFD }=b_{0}+b_{1} X_{1}+b_{2} X_{2}+b_{3} X_{3}+b_{4} X_{4}+e \quad \text { (Model 1) } \\
& \text { YSGD }=b_{0}+b_{1} X_{1}+b_{2} X_{2}+b_{3} X_{3}+b_{4} X_{4}+e \quad(\text { Model 2) } \\
& \text { YED }=b_{0}+b_{1} X_{1}+b_{2} X_{2}+b_{3} X_{3}+b_{4} X_{4}+e \quad(\text { Model 3) }
\end{aligned}
$$




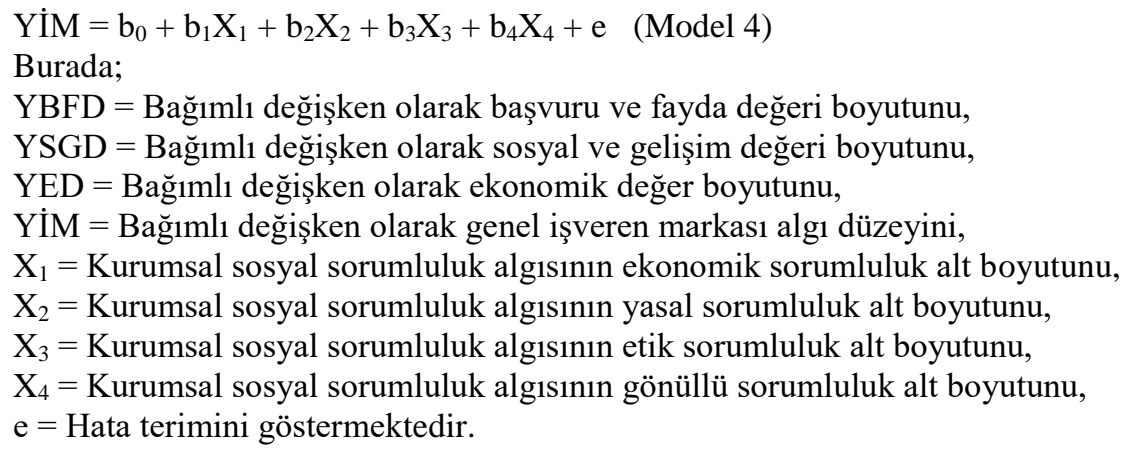

Kurumsal sosyal sorumluluk algı düzeyinin (alt boyutları itibariyle) işveren markasının başvuru ve fayda değeri alt boyutu üzerindeki etkisini test etmek amacıyla yapılan regresyon analizinin sonuçları, Tablo 9'da yer almaktadır. Model 1 'in $\mathrm{F}$ değeri 86,841 olup, model anlamlıdır ( $\mathrm{p}<0,01)$. Her bir bağımsız değişkenin anlamlılık (p) ve B (standardize olmayan beta) değerlerine bakıldığında, kurumsal sosyal sorumluluk algısının bütün alt boyutlarının işveren markasının başvuru ve fayda değeri alt boyutu üzerinde anlamlı ve pozitif bir etkisinin olduğu görülmektedir. Örneğin ekonomik sorumluluk algı düzeyindeki 1 birimlik artış, başvuru ve fayda değeri algı düzeyinde 0,114 birimlik bir artışa yol açmaktadır. Benzer şekilde, gönüllü sorumluluk algı düzeyindeki 1 birimlik artış, başvuru ve fayda değeri boyutunda 0,384 birimlik artışa yol açmaktadır. Bağımsız değişkenlerin önem derecesini gösteren Beta (standardize beta) değerlerine bakıldığında, başvuru ve fayda değeri boyutu üzerinde en önemli etkiye sahip bağımsız değişkenin gönüllü sorumluluklar olduğu (0,396), bunu sırasıyla, etik, ekonomik ve yasal sorumluluk boyutlarının izlediği görülmektedir. Model 1'in düzeltilmiş $\mathrm{R}^{2}$ değeri 0,283 olup, bu değer, bağımsız değişkenlerin bağımlı değişkendeki değişimin \%28,3’ünü açıklayabildiğini göstermektedir.

Doğrusal regresyon analizindeki temel varsayımlardan biri, hata terimleri arasında ilişki (otokorelasyon) olmaması iken, bir diğer varsayım da, bağımsız değişkenler arasında çoklu bağlantı sorunu (multicollinearity) olmamasıdır. Hata terimleri arasında ardışık bağımlılık (ilişki) olup olmadığını test etmek amacıyla Durbin-Watson katsayısına bakılabilir ve katsayının 1,5 ile 2,5 arasında değerler alması istenir (Kalayc1, 2014:264). Model 1'in Durbin-Watson değerine bakıldığında 1,621 olduğu ve istenen değerler arasında yer aldığı görülmektedir. Bağımsız değişkenler arasında çoklu bağlantı sorunu olup olmadığını görmek amacıyla Tolerans veya Varyans Artış Faktörü (VIF, Variance Inflation Factors) değerlerine bakılmaktadır. Düşük tolerans ve yüksek VIF değerleri bağımsız değişkenler arasında çoklu bağlantı olduğunu gösterir (Kalayc1, 2014:264). Uygulamada, genellikle VIF değerinin 10 ve üzerinde olması (VIF $\geq 10$ ), anlamlı çoklu doğrusal bağlantı problemi olduğu şeklinde yorumlanmaktadır (Albayrak, 2005: 110). Model 1'in VIF değerleri 10 'un altında olduğu için bağımsız değişkenler arasında çoklu bağlantı sorunu yoktur. Tablo 8'teki korelasyon değerleri de bağımsız değişkenler arasında yüksek korelasyonun olmadığını göstermektedir.

Tablo 9. Kurumsal Sosyal Sorumluluk Algı Düzeyinin İşveren Markasının Başvuru ve Fayda Değeri Boyutu Üzerindeki Etkisi (Model 1)

\begin{tabular}{|l|c|c|c|c|c|c|}
\hline Değişkenler & $\mathbf{B}$ & Beta & $\mathbf{t}$ & $\mathbf{p}$ & Tolerans & VIF \\
\hline (Sabit) & 0,920 & & 4,959 & 0,000 & & \\
\hline Ekonomik Sorumluluk $\left(\mathrm{X}_{1}\right)$ & 0,114 & 0,090 & 2,851 & 0,004 & 0,821 & 1,219 \\
\hline Yasal Sorumluluk $\left(\mathrm{X}_{2}\right)$ & 0,091 & 0,082 & 2,345 & 0,019 & 0,668 & 1,497 \\
\hline Etik Sorumluluk $\left(\mathrm{X}_{3}\right)$ & 0,124 & 0,101 & 2,869 & 0,004 & 0,662 & 1,510 \\
\hline Gönüllü Sorumluluk $\left(\mathrm{X}_{4}\right)$ & 0,384 & 0,396 & 11,834 & 0,000 & 0,738 & 1,355 \\
\hline $\mathrm{F}=86,841 \quad \mathrm{p}=0,000 \quad \mathrm{R}=0,535$ & $\mathrm{R}^{2}=0,287$ \\
\hline
\end{tabular}

Katılımcıların kurumsal sosyal sorumluluk algı düzeylerinin (alt boyutları itibariyle) işveren markasının sosyal ve gelişim değeri alt boyutu üzerindeki etkisini test etmek amacıyla yapılan regresyon analizinin sonuçları, Tablo 10'da yer almaktadır. Model 2 regresyon modeli anlamlı $(\mathrm{F}=81,294, \mathrm{p}=0,000)$ olup, bağımsız değişkenlerin bağımlı değişkendeki değişimin \%27'sini (Düzeltilmiş $\mathrm{R}^{2}=0,273$ ) açıkladığı görülmektedir. Diğer bir ifadeyle, katılımcıların kurumsal sosyal sorumluluk algı düzeylerinin işveren markasının başvuru ve fayda değeri alt boyutu üzerinde pozitif ve anlamlı bir etkisi vardır. B (standardize olmayan Beta) ve anlamlılık (p) değerleri, kurumsal sosyal sorumluluk algısının bütün alt boyutları ile başvuru ve fayda değeri alt boyutu arasındaki ilişkilerin anlamlı ve pozitif olduğunu, standardize Beta değerleri de başvuru ve fayda değeri üzerinde en önemli etkiye sahip bağımsız değişkenin gönüllü sorumluluklar $(0,312)$ olduğunu göstermektedir. Önem derecesi açısından, gönüllü sorumlulukların ardından yasal sorumluluklar $(0,159)$ gelmekte, ekonomik ve etik sorumluluklar arasında önemli bir farklılık bulunmamaktadır. Model 2'nin Durbin-Watson katsayısı $(1,647)$ otokorelasyon sorunu olmadığını göstermektedir. Bağımsız değişkenler aynı olduğu için, Tolerans ve VIF değerleri Model 1 ile aynı çıkmıştır, dolayısıyla çoklu bağlantı sorunu da söz konusu değildir. 
Anbar, D., Çiftçioğlu, B., A., Anbar, A. / Journal of Yasar University, 2020, 15/58, 221-235

Tablo 10. Kurumsal Sosyal Sorumluluk Algı Düzeyinin İşveren Markasının Sosyal ve Gelişim Değeri Boyutu Üzerindeki Etkisi (Model 2)

\begin{tabular}{|l|c|c|c|c|c|c|}
\hline Değişkenler & $\mathbf{B}$ & Beta & $\mathbf{t}$ & $\mathbf{p}$ & Tolerans & VIF \\
\hline (Sabit) & 1,639 & & 10,647 & 0,000 & & \\
\hline Ekonomik Sorumluluk $\left(\mathrm{X}_{1}\right)$ & 0,109 & 0,105 & 3,288 & 0,001 & 0,821 & 1,219 \\
\hline Yasal Sorumluluk $\left(\mathrm{X}_{2}\right)$ & 0,145 & 0,159 & 4,495 & 0,000 & 0,668 & 1,497 \\
\hline Etik Sorumluluk $\left(\mathrm{X}_{3}\right)$ & 0,108 & 0,107 & 3,016 & 0,003 & 0,662 & 1,510 \\
\hline Gönüllü Sorumluluk $\left(\mathrm{X}_{4}\right)$ & 0,249 & 0,312 & 9,246 & 0,000 & 0,738 & 1,355 \\
\hline $\mathrm{F}=81,294 \quad \mathrm{p}=0,000 \quad \mathrm{R}=0,523$ & $\mathrm{R}^{2}=0,273 \quad$ Düzeltilmiş $\mathrm{R}^{2}=0,27 \quad$ Durbin-Watson: 1,647 \\
$\mathrm{p}<0,05 \quad$ Bağımlı Değişken: Sosyal ve Gelişim Değeri Boyutu
\end{tabular}

Katılımcıların kurumsal sosyal sorumluluk algı düzeylerinin (alt boyutları itibariyle) işveren markasının ekonomik değer alt boyutu üzerindeki etkisini test etmek amacıyla yapılan regresyon analizinin sonuçları, Tablo 11'de yer almaktadır. Kurumsal sosyal sorumluluk algı düzeyleri ile ekonomik değer alt boyutu arasındaki ilişkiyi gösteren regresyon modeli (Model 3) anlamlıdır $(\mathrm{F}=31,299, \mathrm{p}=0,000)$ ve modelin düzeltilmiş $\mathrm{R}^{2}$ değeri 0,123'tür. Dolayısıyla, kurumsal sosyal sorumluluk algı düzeyiyle ilgili alt boyutlar, işveren markası algısının ekonomik değer alt boyutundaki toplam varyansın yaklaşık \%12'sini açıklamaktadır.

Tablo 11. Kurumsal Sosyal Sorumluluk Algı Düzeyinin İşveren Markasının Ekonomik Değer Boyutu Üzerindeki Etkisi (Model 3)

\begin{tabular}{|l|c|c|c|c|c|c|}
\hline Değişkenler & $\mathbf{B}$ & Beta & $\mathbf{t}$ & $\mathbf{p}$ & Tolerans & VIF \\
\hline (Sabit) & 2,871 & & 20,898 & 0,000 & & \\
\hline Ekonomik Sorumluluk $\left(\mathrm{X}_{1}\right)$ & 0,136 & 0,162 & 4,614 & 0,000 & 0,821 & 1,219 \\
\hline Yasal Sorumluluk $\left(\mathrm{X}_{2}\right)$ & 0,109 & 0,146 & 3,764 & 0,000 & 0,668 & 1,497 \\
\hline Etik Sorumluluk $\left(\mathrm{X}_{3}\right)$ & 0,013 & 0,016 & 0,401 & 0,689 & 0,662 & 1,510 \\
\hline Gönüllü Sorumluluk $\left(\mathrm{X}_{4}\right)$ & 0,097 & 0,149 & 4,021 & 0,000 & 0,738 & 1,355 \\
\hline $\mathrm{F}=31,299 \quad \mathrm{p}=0,000 \quad \mathrm{R}=0,356$ & \multicolumn{2}{|l|}{$\mathrm{R}^{2}=0,127$} \\
$\mathrm{p}<0,05$ Düzeltilmiş $\mathrm{R}^{2}=0,123$ & Durbin-Watson: 1,888 \\
\hline
\end{tabular}

Model 3, bir bütün olarak anlamlı olmakla birlikte, p değerlerine bakıldığında, etik sorumlulukların ekonomik değer alt boyutu üzerinde istatistiki olarak anlamlı bir etkisinin olmadığı, kalan kurumsal sosyal sorumluluk algısı boyutlarının ise ekonomik değer alt boyutu üzerinde anlamlı ve pozitif etkiye sahip oldukları görülmektedir. Standardize Beta değerlerine göre, göreli olarak en önemli bağımsız değişken ekonomik sorumluluklardır. Model 1 ve Model 2'de en önemli bağımsız değişken gönüllü sorumluluklar iken, işveren markasının ekonomik değer alt boyutu üzerinde en önemli etkiye sahip bağımsız değişken ekonomik sorumluluk boyutudur.

Katılımcıların kurumsal sosyal sorumluluk algı düzeylerinin (alt boyutları itibariyle) genel işveren markası algı düzeyi üzerindeki etkisini test etmek amacıyla yapılan regresyon analizinin sonuçları, Tablo 12'de yer almaktadır. Model 4, üniversite öğrencilerinin kurumsal sosyal sorumluluk algı düzeyleri ile işveren markası algı düzeyleri arasında pozitif ve anlamlı bir ilişki olduğunu göstermektedir $\left(F=106,887, p=0,000, R^{2}=0,331\right)$. Düzeltilmiş $\mathrm{R}^{2}$ değeri, kurumsal sosyal sorumluluk algısı boyutlarının, işveren markası algı düzeyindeki toplam varyansın yaklaşık \%33'ünü açıkladığını göstermektedir. Modelin Durbin-Watson değeri $(1,529)$ otokorelasyon sorunu olmadığını göstermektedir.

Tablo 12. Kurumsal Sosyal Sorumluluk Algı Düzeyinin Genel İşveren Markası Algı Düzeyi Üzerindeki Etkisi (Model 4)

\begin{tabular}{|l|c|c|c|c|c|c|}
\hline Değişkenler & $\mathbf{B}$ & Beta & $\mathbf{t}$ & $\mathbf{p}$ & Tolerans & VIF \\
\hline (Sabit) & 1,624 & & 12,241 & 0,000 & & \\
\hline Ekonomik Sorumluluk $\left(\mathrm{X}_{1}\right)$ & 0,117 & 0,126 & 4,118 & 0,000 & 0,821 & 1,219 \\
\hline Yasal Sorumluluk $\left(\mathrm{X}_{2}\right)$ & 0,114 & 0,139 & 4,071 & 0,000 & 0,668 & 1,497 \\
\hline Etik Sorumluluk $\left(\mathrm{X}_{3}\right)$ & 0,092 & 0,102 & 2,985 & 0,003 & 0,662 & 1,510 \\
\hline Gönüllü Sorumluluk $\left(\mathrm{X}_{4}\right)$ & 0,271 & 0,378 & 11,661 & 0,000 & 0,738 & 1,355 \\
\hline
\end{tabular}


Anbar, D., Çiftçioğlu, B., A., Anbar, A. / Journal of Yasar University, 2020, 15/58, 221-235

\begin{tabular}{|lllll|}
\hline $\mathrm{F}=106,887$ & $\mathrm{p}=0,000$ & $\mathrm{R}=0,575$ & $\mathrm{R}^{2}=0,331 \quad$ Düzeltilmiş $\mathrm{R}^{2}=0,328$ & Durbin-Watson: 1,529 \\
$\mathrm{p}<0,05$ & Bağımlı Değişken: İşveren Markası Algı Düzeyi (Genel)
\end{tabular}

Model 4'te, standardize olmayan B ve p (anlamlılık) değerlerine bakıldığında, bütün bağımsız değişkenlerin, diğer bir ifadeyle, kurumsal sosyal sorumluluk algısı boyutlarının hepsinin, işveren markası algı düzeyi üzerinde anlamlı ve pozitif etkiye sahip olduğu görülmektedir. Standardize Beta değerleri ise, bağımsız değişkenlerin işveren markası algı düzeyi üzerindeki göreli önem sırasının, gönüllü sorumluluklar $(0,378)$, yasal sorumluluklar $(0,139)$, ekonomik sorumluluklar $(0,126)$ ve etik sorumluluklar $(0,102)$ şeklinde olduğunu göstermektedir.

Model 1, Model 2, Model 3 ve Model 4 regresyon analizlerinin bulguları bir bütün olarak değerlendirildiğinde, üniversite öğrencilerinin kurumsal sosyal sorumluluk algı düzeylerinin hem işveren markası algısının alt boyutları (başvuru ve fayda değeri, sosyal ve gelişim değeri ile ekonomik değer) hem de işveren markası algısının geneli üzerinde anlamlı ve pozitif bir etkiye sahip olduğu görülmektedir. Diğer bir ifadeyle, araştırmanın bulguları, katılımcıların kurumsal sosyal sorumluluk algıları ile işveren markası algıları arasında bir ilişki olduğunu, kurumsal sosyal sorumluluk faaliyetlerinin işveren markası üzerinde olumlu bir etkisinin olduğunu göstermektedir.

\section{Sonuc}

Bu çalışmanın amacı, üniversite öğrencilerinin kurumsal sosyal sorumluluk algılarının işveren markası algıları üzerinde bir etkisinin olup olmadığını ortaya koymaktır. Bu bağlamda 869 katılımcıdan anket tekniği kullanılarak veri toplanmıştır. Çalışmanın bulguları, katılımcıların kurumsal sosyal sorumluluk algı düzeylerinin genel olarak yüksek olduğunu göstermektedir. Kurumsal sosyal sorumluluk algısının alt boyutları bazında, katılımcıların algısının en yüksek olduğu boyut yasal sorumluluk olup, bunu sırasıyla ekonomik, etik ve gönüllü sorumlulukların izlediği görülmektedir. Bu bulgular, katılımcıların işletmelerden öncelikle yasalara uygun olarak faaliyet göstermelerini beklediklerini ortaya koymaktadır. Aslında katılımcıların algı düzeyleri, Carroll (1979, 1991)'un kurumsal sosyal sorumluluk piramidini doğrular şekilde ortaya çıkmıştır. Çünkü Carroll'a göre, işletmeler öncelikle ekonomik sorumluluklarını daha sonrasında sırasıyla yasal, etik ve gönüllü sorumluluklarını yerine getirmelidirler. Çalışmanın bulguları ile Carroll'un piramidi arasındaki tek farklılık, yasal sorumlulukların ekonomik sorumlulukların önüne geçmiş olmasıdır. Diğer bir ifadeyle, katılımcılar, işletmelerin kar odaklı çalışmalarından ziyade yasalara uygun olarak faaliyet göstermeleri gerektiğine daha fazla önem vermektedirler.

Bir işletmeye/kuruma iş başvurusu yaparken işletmeyle/kurumla ilgili olarak, hangi özelliklerin ne kadar önemli olduğunu veya işverenlerde hangi özelliklerin arandığını ortaya koymak amacıyla, katılımcıların işveren markası algı düzeyleri ölçülmüştür. Çalışmanın bulguları, katılımcıların işveren markası algı düzeylerinin genel olarak yüksek olduğunu göstermektedir. Diğer bir ifadeyle, öğrenciler, işveren çekiciliğini ifade eden özelliklerin kendileri için "önemli”" olduğunu ifade etmişlerdir. İşveren markasının alt boyutları bazında, katılımcıların en fazla iş güvencesi, maaş, maaş dışındaki prim, ikramiye vb. maddi yan haklar gibi ekonomik özelliklere önem verdikleri; sonrasında, çalışma arkadaşlarıyla ve üstlerle iyi ilişkiler içinde olunması, yönetim tarafindan takdir edilme, kariyer hedefleri doğrultusunda iş tecrübesi kazandırması gibi özellikleri içinde barındıran sosyal ve gelişim değerine; son olarak da müşteri odaklı olması, kazandıklarının bir kısmını topluma geri vermesi, kaliteli mal/hizmetler üretmesi gibi özellikleri kapsayan başvuru ve fayda değerine önem verdikleri görülmektedir.

Çalışmanın temel amacı kapsamında, kurumsal sosyal sorumluluk algısı ile işveren markası algısı arasında bir ilişki olup olmadığı incelenmiş ve bu kapsamda katılımcıların kurumsal sosyal sorumluluk algı düzeylerinin hem işveren markası algısının geneli üzerinde hem de alt boyutları üzerinde anlamlı ve pozitif bir etkisinin olduğu bulgusuna ulaşılmıştır. Diğer bir ifadeyle, katılımcıların kurumsal sosyal sorumluluk algı düzeyleri ile işveren markası algı düzeyleri arasında pozitif yönlü bir ilişki vardır. Bu bulgular, kurumsal sosyal sorumluluk faaliyetleri yürüten işletmelerin işveren markası algılarının da daha yüksek olacağını, dolayısıyla işletmelerin kurumsal sosyal sorumluluk faaliyetlerine önem vermeleri gerektiğini göstermektedir. Kurumsal sosyal sorumluluk algı düzeyi yüksek olan potansiyel çalışanlar, topluma, çevreye ve çalışanlara karşı sorumluluklarını yerine getiren işletmeleri "çalışılabilecek daha iyi kurum" olarak değerlendirmektedirler. İşletmeler yetenekli çalışanları bünyelerine katmak ve mevcut çalışanların kuruma olan bağlılıklarını arttırmak amacıyla işveren markası oluşturma ve yönetme sürecinde kurumsal sosyal sorumluluk faaliyetlerinin öneminin farkında olmalıdırlar. Elbette, işletmelerin sadece kurumsal sosyal sorumluluk faaliyetleri yürütmeleri yeterli olmayıp, bu faaliyetlere ilişkin bilgilendirmenin de yapılması önem taşımaktadır. Potansiyel ve mevcut çalışanlar söz konusu kurumun kurumsal sosyal sorumluluk faaliyetlerine ilişkin bilgileri veya farkındalıkları yoksa kurumsal sosyal sorumluluk faaliyetlerinin işveren markası algısı üzerindeki olumlu etkisinden bahsetmek de söz konusu olmayacaktır. Bu nedenle, işletmeler internet sitelerini ve diğer iletişim kanallarını kullanarak kurumsal sosyal sorumluluk faaliyetleri kapsamında yürüttükleri çalışmaları kamuoyu ile paylaşmalıdırlar. 
Anbar, D., Çiftçioğlu, B., A., Anbar, A. / Journal of Yasar University, 2020, 15/58, 221-235

\section{KAYNAKÇA}

Albayrak, Ali Sait. 2005. “Çoklu Doğrusal Bağlantı Halinde En Küçük Kareler Tekniğinin Alternatifi Yanlı Tahmin Teknikleri ve Bir Uygulama”, ZKÜ Sosyal Bilimler Dergisi, 1(1): 105-126.

Albayrak, Eda, Esmanur Koç, Seren Oğuztürk, Neslihan Kesgin, Nurefşan Derdiyok. 2019. "Hizmet Sektöründe İşveren Markası Algısı ile Örgütsel Bağlılıkları Arasındaki İlişki”, Ekonomi İşletme ve Maliye Araştırmaları Dergisi, 1(3): 280-293.

Albinger, Heather Schmidt, Sarah J. Freeman. 2000. “Corporate Social Performance and Attractiveness as an Employer to Different Job Seeking Populations", Journal of Business Ethics, 28(3):243-253.

Alnıaçık, Esra, Ümit Alnıaçık, Serhat Erat, Kültigin Akçin. 2014. "Attracting Talented Employees to the Company: Do We Need Different Employer Branding Strategies in Different Cultures?", Procedia - Social and Behavioral Sciences, 150:336- 344.

Alparslan, Ajar, Mehmet Aygün. 2013. "Kurumsal Sosyal Sorumluluk ve Firma Performans1", Süleyman Demirel Üniversitesi Iktisadi ve İdari Bilimler Fakültesi Dergisi, 18(1): 435-448.

Ambler, T., S. Barrow. 1996. "The Employer Brand”, Journal of Brand Management, 4(3):185-206.

Arachchige, B., A Robertson. 2011. "Business Student Perceptions of a Preferred Employer: A Study Identifying Determinants of Employer Branding”, The IUP Journal of Brand Management, 8(3): 25-46.

Ardıç, Kadir, Emine Gündoğmuş. 2016. "Bireylerin Kişilik Özelliklerinin İşveren Çekiciliği Algısına Etkisi”, Journal of Behavior at Work, 1(1): 1-14.

Backhaus, Kristin, Surinder Tikoo, “Conceptualizing And Researching Employer Branding”, Career Development International, 9(5):501-517.

Barrow, S., R. Mosley. 2005. The Employer Brand: Bringing The Best of Brand Management to People At Work, Wiley, New Jersey.

Bellou, Victoria, Ioannis Chaniotakis, Ioannis Kehagias, Irini Rigopoulou. 2015. "Employer Brand of Choice: An Employee Perspective", Journal of Business Economics and Management, 16(6):1201-1215.

Berthon, Pierre, Michael Ewing, Li Lian Hah. 2005. "Captivating Company: Dimensions of Attractiveness in Employer Branding", International Journal of Advertising, 24(2): 151-172.

Bustamante, Silke, Klaus Brenninger. 2013. "CSR and its Potential Role in Employer Branding", 1-27, https://www.researchgate.net/profile/Klaus_Brenninger /publication/262047599_CSR_and_its_Potential_Role_in_Employer_Branding_an_Analysis_of_Preferences_of_German__Graduates_-/ data/0deec5367cc1255be2000000/ WorkplaceCSR.pdf, (25.02.2019)

Bustamante, Silke. 2018. "CSR, Trust and the Employer Brand", Working Papers of the Institute of Management Berlin at the Berlin School of Economics and Law, Paper No. 96.

Carroll, Archie B. 1979. “A Three-Dimensional Conceptual Model of Corporate Performance”, Academy of Management Review, 4(4): 497-505.

Carroll, Archie B. 1991. "The Pyramid of Corporate Social Responsibility: Toward the Moral Management of Organizational Stakeholders", Business Horizons, 34(4): 39-48.

Çiftçioğlu, Aydem. 2014. "Dimensional Analysis of Employer Branding Perceptions of Current Employees". Çanakkale Onsekiz Mart Üniversitesi Dr. H. İbrahim Bodur Girişimcilik Uygulama ve Araştırma Merkezi, 9(2): 417-432.

Davies, Gary. 2008. "Employer Branding and its Influence on Managers", European Journal of Marketing, 42(5/6): 667681.

Dursun, Mehmet Tahir, Engin Deniz Eriş. 2018. “Konaklama İşletmelerinde Kuşaklar Bağlamında İşveren Marka Algısı İle Çalışma Yaşam Kalitesi İlişkisi”, Nevşehir Hacı Bektaş Veli Üniversitesi SBE Dergisi, 8(1):160-179.

Ergun, Hande Sinem, Berivan Tatar. 2018. "Employer Branding and Employee Attitudes: Mediating Role of PersonOrganization Fit", Research Journal of Business and Management, 5(2):110-120.

Erkanlı, Hülya, Volkan Yusuf Topuz ve Ruziye Cop, “Kişilik ve Bireysel Değerlerin İşveren Marka Çekiciliği Algısına Etkisi: İşletme Bölümü Öğrencileri Üzerine Bir Örnek Uygulama”, İstanbul Üniversitesi Siyasal Bilgiler Fakültesi Dergisi, 52: 85-107.

Ersoy, Iris, Zeynep Akşehirli. 2015. "Effects of Perceptions of Corporate Social Responsibility on Employer Attractiveness", Research Journal of Business and Management, 2(4):507-518.

Fernandez-Lores, Susana, Diana Gavilan, Maria Avello, Francisca Blasco. 2016. "Affective Commitment to the Employer Brand: Development and Validation of a Scale”, BRQ Business Research Quarterly, 19:40-54.

Greening, Daniel W., Daniel B. Turban. 2000. "Corporate Social Performance as a Competitive Advantage in Attracting a Quality Workforce", Business and Society, 39(3):254-280.

Gözen, Ebru. 2006. "Potansiyel İşgörenler Açısından İşveren Markası Algısı: Akdeniz Üniversitesi Turizm Öğrencileri Örneği”, Journal of Tourism and Gastronomy Studies, 4(1): 70-80.

Güler, Murat, H. Nejat Basım, 2018. "İşveren Markası, Örgütsel Çekicilik ve Organizasyona Katılma Niyeti İlişkisi: Görgül Bir Araştırma”, Social Sciences Studies Journal, 4(21): 3659-3673.

Güngördü, Aybegüm, Emre Burak Ekmekçioğlu, Tuğçe Şimşek. 2014. "İçsel Pazarlama Bağlamında İşveren Markalaması Üzerine Ampirik Bir Çalışma”, Journal of Management and Logistics, 1(1):1-15. 
Anbar, D., Çiftçioğlu, B., A., Anbar, A. / Journal of Yasar University, 2020, 15/58, 221-235

Hillebrandt, Isabelle, Björn Sven Ivens. 2012. "How to Measure Employer Brands? The Development of a Comprehensive Measurement Scale”, Ed.: Sundar Bharadwaj, John Hulland, Marketing Theory and Applications, American Marketing Association.

Hinson, Robert Ebo, Selorm Agbleze, John Kuada. 2018. “Corporate Social Responsibility and Employer Attractiveness: Perspectives of Prospective Jobseekers in Ghana", African Journal of Business Ethics, 12(2):1- 17.

Ibrahim, Nayera Ahmed Fouad. 2017. "The Relationship between Corporate Social Responsibility and Employer Attractiveness in Egypt: The Moderating Effect of the Individual's Income", Contemporary Management Research Management, 13(2):81-106.

Jain, Sonal. 2013. "Employer Branding and its Impact on CSR, Motivation, and Retention of Employees Using Structural Equation Modelling", Delhi Business Review, 14(2):83-98.

Kahveci, Nergis Ecenur. 2018. Y Kuşağının İşyeri Seçimini Etkileyen Faktörler: İşveren Markası ve Sosyo-Demografik Özellikler, (Yüksek Lisans Tezi), İstanbul: Bahçeşehir Üniversitesi Sosyal Bilimler Enstitüsü.

Kalaycı, Şeref. 2014. SPSS Uygulamalı Çok Değişkenli İstatistik Teknikleri, Asil Yayın Dağıtım, Ankara.

Kara, Melike Nur. 2013. İşveren Markası İle Örgütsel Bağlılık Arasındaki İlişki: Bilişim Sektöründe Bir Uygulama, (Yüksek Lisans Tezi), Bursa: Uludağ Üniversitesi Sosyal Bilimler Enstitüsü.

Karaman, Haydar, Burcu Atar, Derya Çobanoğlu Aktan. 2017. "Açımlayıcı Faktör Analizinde Kullanılan Faktör Çıkartma Yöntemlerinin Karşılaştırılması”, Gazi Üniversitesi Gazi Eğitim Fakültesi Dergisi, 37(3): 1173-1193.

Kashikar-Rao, Mrinal. 2014. "Role of CSR in Employer Branding: Emerging Paradigm”, Review of HRM, 3:188-195.

Klimkiewicz, Katarzyna, Victor Oltra. 2014. "Does CSR Enhance Employer Attractiveness? The Role of Millennial Job Seekers' Attitudes", Corporate Social Responsibility and Environmental Management, 3:188-195.

Köse, Gonca, Sinem Yeygel Çakır. 2015. “İşveren Markası Yönetim Sürecinde Strateji Ve Uygulamaların İncelenmesi: Türkiye'deki Şirketlerin İnsan Kaynakları Yöneticilerine Yönelik Bir Araştırma”, Uluslararası Sosyal Araştırmalar Dergisi, 8(40): 674-689.

Köse, Gonca. 2017. Reklam Ajanslarına İşveren Markası Bakışı, 1.b., Ankara: Detay Yayıncılık.

Köse, Gonca. 2018. "İnsan Kaynakları Yönetiminin Derin İçgörüsü: Yetenek Yönetimi ve İşveren Markası İlişkisi”, Uluslararası Sosyal Araştırmalar Dergisi, 11(56):823-833.

Kucherov Dmitry, Elena Zavyalova. 2012. "HDR Practices and Talent Management in The Companies With The Employer Brand", European Journal of Training and Development, 36(1):86-104.

Kuşçu, Aslı, Elif Yolbulan Okan. 2010. "An Exploratory Study on the Dimensions of Employer Branding”, Marmara Üniversitesi Sosyal Bilimler Enstitüsü Dergisi, 9(34): 119-130.

Maheshwari, Sunil, Rama Shankar Yadav. 2015. "Is CSR a Hygiene Factor for Prospective Employees? An Indian Exploration", The Indian Journal of Industrial Relations, 50(4):601-612.

Mölk, Andreas, Manfred Aurer. 2018. "Designing Brands And Managing Organizational Politics: A Qualitative Case Study Of Employer Brand Creation”, European Management Journal, 36(4):485-496.

Narcıkara, Elif, Yonca Gürol, Ahmet Üzmez. 2016. "İşveren Markası Oluşturma: Katılım Bankası Örneği”, İşletme \& Sosyal Bilimler Araştırmaları Dergisi, 5(2):45-58.

Ötken, Ayşe Begüm, Elif Yolbulan Okan. 2015. Şimdi İşveren Markası Zamanı, 1.b., İstanbul: Türkmen Yayınevi.

Raj, Ashabinu, P. Jyothi. 2011. "Internal Branding: Exploring The Employee Perspective", Journal of Economic Development, Management, IT, Finance and Marketing, 3(2):1-27.

Rampl, Linn Viktoria, Peter Kenning. 2014. "Employer Brand Trust and Affect: Linking Brand Personality to Employer Brand Attractiveness", European Journal of Marketing, 48(1/2):218-236.

Reis, Germano Glufke, Beatriz Maria Braga. 2016. "Employer Attractiveness from a Generational Perspective: Implications for Employer Branding”, Revista de Administraçao Sao Paulo (RAUPS), 51(1):103-116.

Roy, Sanjit Kumar. 2008. "Identifying The Dimensions of Attractiveness of an Employer Brand in the Indian Context", South Asian Journal of Management, 15(4):110-130.

Sağır, Mehmet. 2016. "İşveren Markası Algısı: İnsan Kaynakları Faaliyetleri, Çalışma Ortamı ve Tazminat-Kazanç Boyutları İle Turizm Fakültelerinde Bir Uygulama”, Mehmet Akif Ersoy Üniversitesi Sosyal Bilimler Enstitüsü Dergisi, 8(14): 415-439.

Saruhan Yalça, Muazzez. 2017. “İ̧şveren Markalaşmasında İşveren Çekiciliğinin Farklı Boyutlarına Verilen Önemin Çalışanların Demografik Özellikleri Temelinde Farklılaşması”, (Yüksek Lisans Tezi), İstanbul: Beykent Üniversitesi Sosyal Bilimler Enstitüsü.

Saylan, Onur, Umut Eroğlu. 2019. "Meslek Yüksekokulu Öğrencilerinin İşveren Marka Algısı Boyutlarının Belirlenmesi Üzerine Bir Araştırma”, 8th International Vocational Schools Symposium, UMYOS'19, SINOP.

Sharma, Ruchika, Asha Prasad. 2018. "Employer Brand and its Unexplored Impact on Intent to Join", International Journal of Organizational Analysis, 26(3):536-566.

Sivertzen, A., E. Nilsen, A. Olafsen. 2013. "Employer Branding: Employer Attractiveness and the Use of Social Media", Journal of Product \& Brand Management, 22(7):473-483.

Srivastava, Pallavi, Jyotsna Bhatnagar, Ashok Pratap Arora. 2017. "A Multi-dimensional Scale for Measuring Employer Brand", Indian Journal of Industrial Relations, 52(4): 659-674.

Tanwar, Karnica, Asha Prasad. 2016. "The Effect of Employer Brand Dimensions on Job Satisfaction: Gender as a Moderator", Management Decision, 54(4):854-886. 
Anbar, D., Çiftçioğlu, B., A., Anbar, A. / Journal of Yasar University, 2020, 15/58, 221-235

Tkalac Verčič, Ana, Dubravka Sinčić Ćorić. 2018. "The Relationship Between Reputation, Employer Branding and Corporate Social Responsibility”, Public Relations Review, 44(4):444-452.

Tüzüner, Lale V. 2019. "Segmenting Potential Employees According to Firms' Employer Attractiveness Dimensions in The Employer Branding Concept", Journal of Academic Research in Economics, 1(1):46-61.

Yorulmaz, Funda, Öznur Yavan. 2018. "Pozitif Psikolojik Sermayenin İşveren Marka Oluşumu Üzerindeki Etkisi: Turizm Sektörü Örneği”, Atatürk Üniversitesi Sosyal Bilimler Enstitüsü Dergisi, 22(2):1007-1027.

Wilden, Ralf, Siegfried Gudergan, Ian Lings. 2010. "Employer Branding: Strategic Implications for Staff Recruitment", Journal of Marketing Management, 26(1-2): 56-73. 